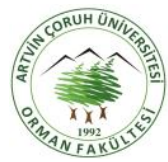

\title{
Balıkesir-Burhaniye yöresi fıstıkçamı (Pinus pinea L.) ağaçlandırmalarında bazı fizyografik etmenlerle çap, boy ve kozalak özellikleri arasındaki ilişkiler
}

\section{Correlations between some physiographic factors and diameter, height and cone characteristics in stone pine (Pinus pinea L.) afforestation areas in Balıkesir-Burhaniye region}

\author{
Ali Ömer ÜÇLER ${ }^{1}$, Mustafa ARPACl ${ }^{2}$ \\ 'Karadeniz Teknik Üniversitesi, Orman Fakültesi, Orman Mühendisliği Bölümü, Trabzon, Türkiye \\ ${ }^{2}$ Sakarya Orman Bölge Müdürlüğü, Hendek Orman İşletme Müdürlüğü, Adapazarı, Türkiye
}

\author{
Eser Bilgisi / Article Info \\ Araştırma makalesi / Research article \\ DOI: 10.17474/artvinofd.313936 \\ Sorumlu yazar / Corresponding author \\ Ali Ömer ÜÇLER \\ e-mail: ucler@ktu.edu.tr \\ ORCID: 0000-0001-5372-6786 \\ Geliş tarihi / Received \\ 17.05.2017 \\ Düzeltme tarihi / Received in revised form \\ 02.10.2017 \\ Elektronik erișim / Online available \\ 31.10.2017 \\ Anahtar kelimeler: \\ Pinus pinea \\ Ağaçlandırma \\ Fizyografik faktörler \\ Boy \\ Çap \\ Kozalak özellikleri
}

\section{Keywords:}

Pinus pinea

Afforestation

Physiographic factors

Height

Diameter

Cone characteristics

\section{Özet}

Bu çalışmada, bazı fizyografik etmenlerin (bakı, eğim ve yükselti) Balıkesir-Burhaniye yöresi fıstıkçamı (Pinus pinea L.) ağaçlandırmalarının çap ve boy değerleri ile kozalak özellikleri (kozalak ağırlığı, kozalak sayısı, kozalak eni ve kozalak boyu) üzerine olan etkileri araştırılmıştır. Fizyografik etmenlerin etkilerini belirleyebilmek amacıyla çalışma alanı, bakı, eğim ve yükselti gruplarına ayrılmıştır. Buna göre; gölgeli (B1) ve güneşli (B2) olmak üzere iki bakı grubu, \%36'dan düşük (E1) ve \%36'dan fazla (E2) olmak üzere iki eğim grubu ve 400 m'den düşük (Y1) ve 400 m'den fazla (Y2) olmak üzere iki yükselti grubu oluşturulmuştur. Tabakalı örnekleme yöntemi ile örnek alanlar bu arazi sınıflarına dağıtılmıştır. Çalışma, 32 adet örnek alandan sağlanan verilerle yürütülmüştür. Örnek alanlarda ağaç boyu, göğüs çapı ve kozalak sayısı değerleri ile her örnek alanda 5 adet olmak üzere seçilen örnek ağaçlardan toplanan kozalakların çap, boy ve hava kurusu ağırlık değerleri ölçülmüştür. İstatistiksel değerlendirmelere göre; bakı etmeninin ağaç boyu, kozalak sayısı ve kozalak ağırlığı üzerinde, eğim etmeninin ağaç çapı, kozalak sayısı ve kozalak çapı üzerinde, yükselti etmeninin de ağaç çapı, ağaç boyu, kozalak sayısı ve kozalak ağırlığı üzerinde etkili oldukları belirlenmiştir. Ağaç boy ve çap değerleri bakımından; en yüksek ortalama göğüs çapı $13.6 \mathrm{~cm}$ ile B1E1Y1'de, en yüksek ortalama boy değeri B2E2Y2 ortak etkileşiminde bulunmuştur. Kozalak özellikleri bakımından; en yüksek ortalama kozalak sayısı 8.5 adet ile B1E1Y1'de, en yüksek ortalama kozalak ağırığı 232 gr ile B1E1Y1'de, en yüksek kozalak çapı ise $5.4 \mathrm{~cm}$ ile B2E2Y1 ortak etkileşiminde elde edilmiştir. Korelasyon analizi sonuçlarına göre; göğüs çapı üzerinde eğim ve yükselti etmenlerinin pozitif yönde bir etkisi olduğu belirlenmiştir. Boy üzerinde ise bakı ve yükselti etmenleri pozitif etki göstermektedir. Kozalak sayısı ile bakı ve eğim negatif, yükselti ise pozitif ilişkilidir. Kozalak çapı ile her üç etmen, pozitif ilişki içerisindedir. Kozalak boyu ise, eğim etmeni ile negatif, yükselti etmeni ile pozitif bir ilişki göstermektedir.

\section{Abstract}

In this study, effects of some physiographic factors (aspect, slope and elevation) on breast diameter, height and cone properties (cone weight, number of cones, cone width and cone length) in stone pine (Pinus pinea L.) afforestation areas in Balıkesir-Burhaniye region were investigated. To determine to effects of physiographic conditions, study area is separated according to aspect, slope and elevation groups. Aspect is separated two groups which are shady aspect (B1) and sunny aspect (B2). Slope is separated two groups which are small from 36 percent (E1) and big from 36 percent (E2). Elevation also is separated two groups which are under 400 meters (Y1) and over 400 meters (Y2). Sample areas were scattering to land classifications by using Stratified Sampling Method. Thus, each aspect, slope and elevation classifications were obtained from sample area where are provided from 32 different areas. Tree heights, the diameter at breast height and cone number were measured on saplings. In addition, in each sample area five Pinus pinea trees were selected. It was measured cone diameter, cone height and air-dries weight values of cones which are picked from selecting trees. According to statistical analysis results, aspect effects to tree heights, cone number and cone weight; slope effects the diameter at breast height, cone number and cone diameter; elevation effects the diameter at breast height, tree height, cone number and cone weight. In terms of tree height and diameter values; the highest average breast height diameter was found in the B1E1Y1 with $13.6 \mathrm{~cm}$, and the highest average height value was found in the B2E2Y2 by interaction. In terms of cone characteristics; with the highest average cone number of 8.5 in B1E1Y1, the highest mean cone weight in B1E1Y1 with 232 $\mathrm{gr}$ and the highest cone diameter in B2E2Y1 with $5.4 \mathrm{~cm}$. According to the results of correlation analysis; it was determined that slope and elevation factors have positive effect on breast height diameter. At the same time, aspect and elevation have positive effect on height. Although aspect and slope factors have negative correlation with number of cones, but elevation has positive correlation as well. Both three factors have positive correlation with cone diameter. On the other hand, cone height has negative correlation with slope and positive correlation with elevation. 


\section{GiRiş}

Akdeniz orman ekosisteminin önemli ağaç türlerinden birisi olan fıstıkçamı (Pinus pinea L.) gerek ekolojik, gerek ekonomik ve gerekse estetik özellikleri nedeniyle ağaçlandırmalarda çokça tercih edilmekte ve odun dışı bitkisel orman ürünleri arasında ülke ekonomisine önemli katkı sağlayanların başında türün bir ürünü olan çam fıstığı gelmektedir. Genel olarak ifade etmek gerekirse; fıstıkçamı meşcereleri çam fıstığı, kereste ve yakacak odun üretimi ile rekreasyonel kullanım, peyzaj planlama ve kumul alanlarının rüzgar erozyonuna karşı korunması gibi çok fonksiyonlu amaçları yerine getirmek üzere planlanmaktadır (Moreno-Fernández ve ark. 2013). Gerek odun üretimi ve gerekse kozalak üretimi yapılmasına imkân veren fıstıkçamı meşcereleri, hedeflenen ürünün çeşidine göre farklı idare süreleri ile değerlendirilmektedir. Kozalak üretiminin amaçlandığı meşcerelerde idare süresi 150 yıla çıkarılabilmekte, hem odun üretimi, hem de kozalak üretiminin amaçlandığı meşcereler için ise 120 yıl uygun görülmektedir (Montes ve ark. 2006).

Akdeniz ülkeleri ve güney Avrupa'da tali ürün üretimine yönelik olarak tesis edilen çok fonksiyonlu ağaçlandırmalarda mevcut ekolojik koşullara uygun olması ve yüksek ekonomik kazanç sağlaması nedeniyle yaygın olarak fıstıkçamı tercih edilmektedir (Kırdar ve ark. 2010). Uluslararası pazarlarda çok değerli bir ürün olması nedeniyle, üreticisi olduğu kesime diğer orman ürünlerinden daha fazla gelir sağlamakta (Mutke ve ark. 2005a), yüksek protein, yağ, vitamin, potasyum ve fosfor içeriğiyle, kan basıncı ve kolesterol seviyesi düzenleyicisi olarak tavsiye edilmektedir (Nergiz ve Dönmez 2004).

Dünyada çam fıstığı üretimi yıllık 20.000 tondur. 10000 tonluk yıllık üretimle Çin birinci sırada yer almakta, İspanya, İtalya, Portekiz ve Türkiye bu ülkeyi takip etmektedir. Türkiye'nin yıllık üretimi ise 1200-1300 ton olarak belirtilmektedir (Nergiz ve Dönmez 2004). Ancak, Türkiye yıllık üretiminin güncel değerlendirmelere bakıldığında, son yıllarda önemli oranda arttığı ve yıllık 2000 tonun üzerine çıktığı da ihracat rakamlarından görünen bir gerçektir (Kurt ve ark. 2016). Çam fıstığı üretiminde gözlenen bu üretim artışııın geçmiş yıllarda oluşturulan plantasyonlardan kaynaklandığını söylemek olasıdır. Türkiye'nin çam fıstığı ihracat rakamları incelendiğinde, 1995 yılında 203 ton ile 1.717.000 dolar gelir sağlayan ihracatı, 2000 yıında \%18,3 azalarak 166 tona düştüğü, ancak ihraç geliri miktarının ise tersine \%31,8 artarak 2.263.000 dolara yükselmiş olduğu görülmektedir (Kurt ve ark. 2016). Son yıllarda, çam fıstığının fiyatının beklentilerin de üzerinde değerlenmesi, yerel Orman İşletmelerine ve yöre halkına önemli maddi katkılar sağlamaktadır (URL 2014). Nitekim 2010 yılında, 2000 yılı verilerine kıyasla ihracat miktarı \%1208 artarak 2171,766 tona ulaşmıştır. Bu artışla birlikte ihracat geliri de \%2896 artarak 67.802.000 dolara çıkmıştır (Kurt ve ark. 2016). Bu durum fıstıkçamı ile yapılacak hem kamu hem de özel sektör ağaçlandırmalarının teşvik edilmesinde önemli bir neden oluşturmaktadır. Nitekim 2006 yılı verileri esas alındığında, 59149.7 ha alanda fıstıkçamı plantasyonunun tesis edildiği görülmektedir. Aynı zamanda ülkemizde saf ve karışık halde toplam 33.742 ha saf ve karışık fıstıkçamı ormanı bulunmaktadır (Anonim 2006).

Fıstıkçamı, Portekiz'den Suriye'ye kadar Kuzey ve Doğu Akdeniz Bölgesinin tümünde ve Karadeniz'in bazı kıyı alanları boyunca yayılış yapmakta ve Kuzey Akdeniz'de deniz seviyesinden 500-600 m. ye, doğu Akdeniz'de 800$1400 \mathrm{~m}$ ye çıkabilmektedir (Fady ve ark. 2004). Dolayısıyla fıstıkçamı, Akdeniz fitocoğrafya bölgesinin doğal bir elemanıdır (Atalay, 1994). Anadolu, Lübnan ve iber yarımadası fıstıkçamının muhtemel en özgün alanlarıdır (Fady ve ark. 2004). Türkiye yayılışına bakıldığında; Batı Anadolu'da Bergama yörelerinde, Kozak, Aydın, Muğla yakınlarında geniş meşcereler oluşturur. Ayrıca Manavgat sahillerinde, Marmara yöresinde, Gemlik körfezi kıyılarında, Kahramanmaraş'ta ve Önsen köyünde yayılış göstermektedir (Anşin ve Özkan 1993; Yılmaz ve ark. 2010). Bu genel yayılışı dışında, Doğu Karadeniz sahil ve iç kesimlerinde çok dar ve parçalı halde Trabzon'un Kalenema deresi Düzköy yöresi ve bundan daha geniş olarak Artvin Çoruh vadisinde izlenmektedir (Anşin ve Özkan 1993). Doğal yayılış gösterdiği alanlarındaki eğim düz ya da az eğimli, yükseklik 7 metre ile 980 metre arasında değişmekte ve denizden 110 metre içeriye kadar sokulmaktadır (Sayman ve ark. 2006). 
Araştırmaya konu ağaçlandırma alanının bulunduğu Edremit Körfezi ve yakın çevresinde fıstıkçamı halk tarafından 'akıllı çam' olarak nitelendirilmekte, sağladığı ekonomik gelir nedeniyle orman köylüsü tarafından benimsenip korunmakta, diğer türlerle tesis edilen ağaçlandırma sahalarına göre daha az oranda hayvan baskısı ve tahribatına maruz kalmaktadır. Tüm bu gerekçelerden hareketle çalışmanın amacl; fıstıkçamı ağaçlandırmalarının büyüme performansı ve kozalak verimine fizyografik etmenlerin (bakı, eğim ve yükselti) etkilerini ortaya koymak, böylece fıstıkçamı ile tesis edilecek olan yeni ağaçlandırma alanları için en yüksek büyüme, artım ve kozalak verimliliğini sağlayabilecek kıstasları belirlemektir.

\section{MATERYAL ve YÖNTEM}

\section{Materyal}

Araştırma materyali olarak Balıkesir Orman Bölge Müdürlüğü, Burhaniye yöresi Edremit Orman iş̧letme Müdürlüğü, Bahadınlı Serisi Orman İçi Ağaçlandırma Projesi kapsamında 1985 yılında 1+0 yaşı çıplak köklü olarak dikilmiş olan fıstıkçamı fidanlarının 20 yaşındaki meşcereleri kullanılmıştır (Çizelge 1).

Araştırma alanındaki ölçümler 2004 yılında gerçekleştirilmiştir. Araştırmanın yapıldığı alan 64.27 hektar büyüklüğündedir. Araştırmaya konu fıstıkçamı fidanları için tohumlar Edremit İşletmesi'nin Kumluca bölgesinden temin edilmiştir. Bu tohumlar Balıkesir Fidanlık Müdürlüğü’ne bağlı Edremit Dereli Fidanlığında ekilerek fidanlar elde edilmiştir (Anonim, 1985). Araştırma alanındaki ağaçlandırma çalışmasında $6 \mathrm{~m} \times 6$ $\mathrm{m}$ aralık-mesafe kullanılmıştır. Araştırma alanı Dutluca ve Kızıklı Köyleri arasında yer alan Turnagölü mevkiinde ve Amenajman Planında çok bozuk nitelikli olarak belirtilen orman arazisidir. Araştırma alanına ilişkin UTM koordinatları Xmin: 505600, Xmax: 506900 ve Ymin: 4370500, Ymax: 4371750'dir.

\section{Araştırma alanının genel iklim ve toprak özellikleri}

Araştırma alanında yıllık ortalama sıcaklık $13,5^{\circ} \mathrm{C}$, en sıcak ay Temmuz $\left(23,2^{\circ} \mathrm{C}\right)$ ayı, en soğuk ay Ocak $\left(4,1^{\circ} \mathrm{C}\right)$ ayıdır. Yıllık ortalama yağıs $830 \mathrm{~mm}$ 'dir. Bölgede iklim tipi bakımından, Erinç'in "Yağış müessiriyeti" formülüne göre (Çepel, 1995) yarı nemli iklim tipi hakimdir. Toprak türü, kalkersiz kahverengi orman toprağı tipindedir (Anonim, 1985).

\begin{tabular}{|c|c|c|c|c|}
\hline $\begin{array}{l}\text { Örnek Alan } \\
\text { No }\end{array}$ & Bakı & $\begin{array}{l}\text { Eğim } \\
\text { (\%) }\end{array}$ & $\begin{array}{l}\text { Yükselti } \\
\text { (m) }\end{array}$ & $\begin{array}{l}\text { Birey Sayısı } \\
\text { (adet) }\end{array}$ \\
\hline 1 & Kuzey & 19 & 362 & 40 \\
\hline 2 & Kuzey & 0 & 370 & 40 \\
\hline 3 & Kuzeybatı & 10 & 355 & 40 \\
\hline 4 & Doğu & 8 & 356 & 39 \\
\hline 5 & Doğu & 8 & 359 & 40 \\
\hline 6 & Kuzey & 0 & 413 & 40 \\
\hline 7 & Kuzey & 27 & 423 & 38 \\
\hline 8 & Kuzey & 0 & 442 & 40 \\
\hline 9 & Kuzeybatı & 24 & 405 & 38 \\
\hline 10 & Kuzeybatı & 26 & 450 & 30 \\
\hline 11 & Kuzeybatı & 38 & 387 & 35 \\
\hline 12 & Kuzeybatı & 79 & 338 & 40 \\
\hline 13 & Kuzeybatı & 39 & 362 & 40 \\
\hline 14 & Kuzeybatı & 45 & 363 & 40 \\
\hline 15 & Kuzeybatı & 41 & 380 & 39 \\
\hline 16 & Batı & 15 & 353 & 39 \\
\hline 17 & Batı & 29 & 367 & 40 \\
\hline 18 & Batı & 9 & 358 & 39 \\
\hline 19 & Batı & 27 & 380 & 40 \\
\hline 20 & Batı & 31 & 345 & 35 \\
\hline 21 & Batı & 30 & 428 & 34 \\
\hline 22 & Batı & 20 & 430 & 34 \\
\hline 23 & Batı & 21 & 427 & 39 \\
\hline 24 & Batı & 16 & 435 & 39 \\
\hline 25 & Batı & 22 & 448 & 40 \\
\hline 26 & Batı & 38 & 404 & 37 \\
\hline 27 & Batı & 40 & 408 & 40 \\
\hline 28 & Batı & 37 & 472 & 37 \\
\hline 29 & Batı & 51 & 338 & 35 \\
\hline 30 & Batı & 37 & 367 & 35 \\
\hline 31 & Batı & 44 & 401 & 39 \\
\hline 32 & Batı & 41 & 403 & 38 \\
\hline
\end{tabular}

\section{Yöntem}

\section{Araştırma alanında yapılan ölçümler}

Çalışma alanına ait 1/25000 ölçekli topografik harita, Arcınfo 8.3 programı yardımıyla sayısallaştıııarak bilgisayar ortamına aktarılmış ve bakı, eğim ve yükselti basamakları olmak üzere üç fizyografik etmene göre sınıflandırılmıştır. Buna göre çalışma alanı; gölgeli bakılar (B1) ve güneşli bakılar (B2) olarak iki bakı grubuna ayrılmıştır. Eğim, \%0-36 arasında olan alanlar (E1) ve \%36'dan yüksek eğimli alanlar (E2) olmak üzere iki eğim grubuna, yükselti ise 0-400 $\mathrm{m}$ arasında olan alanlar (Y1) ve $400 \mathrm{~m}$ 'den daha fazla yükseltiye sahip olan alanlar (Y2) olmak üzere iki yükselti grubuna ayrılmıştır. Eğim gruplarının oluşturulmasında Çepel (1995) de belirtilen kriterler esas alınmış ve çalışma alanı "az eğimli", "orta 
eğimli" ve "çok eğimli" alanlar bir grupta (<\%36), "dik" ve "sarp" olarak ifade edilen alanlar ise diğer grupta (>\%36) olmak üzere iki gruba ayrılmıştır. Bakı gruplarında; kuzeybatı, kuzey, kuzeydoğu ve doğu bakıları gölgeli bakılar, diğer bakılar ise güneşli bakılar olarak değerlendirilmiştir. Örnek alanlar bakı sınıflarına göre $15^{\prime} \mathrm{i}$ gölgeli, 17'si güneşli bakıda, eğim sınıflarına göre 20'si eğimi \%36'dan düşük alanlarda, 12'si eğimi \%36'dan yüksek alanlarda ve yükselti sınıflarına göre de 17'si yükseltisi 400 m'nin altında ve $15^{\prime} i$ yükseltisi 400 m'den fazla alanlarda yer almaktadır (Çizelge 1). Çalışma alanı 8 farklı fizyografik özellikte değerlendirmeye tabi tutulmuştur (Çizelge 2). 8 ayrı gruba ayrılmış olan alanın örneklenmesinde örnekleme yöntemi olarak "Tabakalı (Katmanlı) Örnekleme Yöntemi" kullanılmış ve yine her bir tabaka içerisinde "Basit Rasgele Örnekleme Yöntemi" kullanılmıştır. Örnek alanların büyüklüğü $30 \mathrm{~m}$ x $48 \mathrm{~m}$ (1440 m2) olarak alınmıştır. Çalışma alanının tamamında eşit dikim aralık-mesafesi ( $6 \mathrm{~m} \times 6 \mathrm{~m}$ ) kullanılmıs olup, her bir ağaç $36 \mathrm{~m} 2$ alan kapladığından örnek alanlarda 40 (=1440/36) adet bireyde ölçüm yapılması planlanmıştır. Araştırma alanında yapılan ölçümler sırasında B1E2Y2 grubunda yer alan örnek alanlarda yeterli örnek alan büyüklüğü olmaması ve fiilen birey yer almaması (yollar ve yangın emniyet yolları nedeniyle) nedeniyle ölçüm yapılmamıştır. Yine B2Y2E1 grubunda bazı örnek alanlarda dikim aralık mesafesinin düzensiz olması nedeniyle araştırma sonuçlarının sağlıklı olması açısından sadece 2 adet örnek alanda ölçümler gerçekleştirilmiştir. Böylece 40 adet olarak tasarlanan örnek alan sayısı 32'ye düşmüştür. Kozalak verimliliğinin ortaya konabilmesi için örnek alandaki tüm ağaçlardaki kozalaklar sayılmıştır. Her örnek alanda rasgele seçilmiş 5 adet ağacın kozalakları toplanarak bunların hava kurusu ağılıkları ile her kozalağın çapı ve boyu ölçülmüştür.

\section{İstatistik analizler}

Örnek alanlarda yapılan ölçüm verileri SPSS 11.0 istatistik paket programı yardımıyla analiz edilerek her bir etmenin değişkenler üzerine olan etkileri "t testi" kullanılarak, etmenlerin değişkenler üzerine birlikte etkileri ise, "varyans analizi" yardımıyla belirlenmeye çalışılmıştır. Varyans analizinde anlamlı bir farklılığın çıkması durumunda, gruplandırmalar Duncan testi ile gerçekleştirilmiş ve istatistik denetimler $p<0,05$ güven düzeyinde yapılmıştır. Boy, göğüs çapı, kozalak sayısı, kozalak ağırlığı, kozalak boyu ve kozalak çapı gibi bireylere ait değişkenler ile bu değişkenler üzerinde etkinliği araştırılan bakı, eğim ve yükselti etmenleri arasındaki ilişkiyi belirlemek için "korelasyon analizi" uygulanmıştır (Batu 1995; Özdamar 2002). Çalışmada korelasyon testleri yapılırken bakı, eğim ve yükseltinin Çizelge 2'de gösterildiği şekliyle sınıflandırma değerleri dikkate alınmıştır. Bu çalışmada sıralanmış nitel değişkenler Çizelge 2'ye göre yapılmış, korelasyon analizi ise Pearson (r) ilişki katsayısı esas alınarak hesaplanmıştır.

Çizelge 2 Araştırma alanının fizyografik etmenlere göre sınıflandırılması

\begin{tabular}{|c|c|c|c|c|c|}
\hline \multicolumn{2}{|c|}{ Bakı } & \multicolumn{2}{|c|}{ Eğim } & \multicolumn{2}{|c|}{ Yükselti } \\
\hline $\begin{array}{l}\text { Gölgeli } \\
\text { (B1) }\end{array}$ & $\begin{array}{l}\text { Güneşli } \\
\text { (B2) }\end{array}$ & $\begin{array}{c}<\% 36 \\
(\mathrm{E} 1)\end{array}$ & $\begin{array}{c}>\% 36 \\
(E 2)\end{array}$ & $\begin{array}{c}<400 \mathrm{~m} \\
(\mathrm{Y} 1)\end{array}$ & $\begin{array}{c}>400 \mathrm{~m} \\
(\mathrm{Y} 2)\end{array}$ \\
\hline Bakı grupları & Eğim Grupları & Yükselti Grupları & Grup Adı & & \\
\hline \multirow[t]{4}{*}{ Gölgeli (B1) } & $<\% 36$ (E1) & $<400 \mathrm{~m}(\mathrm{Y} 1)$ & B1E1Y1 & & \\
\hline & & $>400 \mathrm{~m}(\mathrm{Y} 2)$ & B1E1Y2 & & \\
\hline & $>\% 36$ (E2) & $<400 \mathrm{~m}(\mathrm{Y} 1)$ & B1E2Y1 & & \\
\hline & & $>400 \mathrm{~m}(\mathrm{Y} 2)$ & B1E2Y2 & & \\
\hline \multirow[t]{4}{*}{ Güneşli (B2) } & $<\% 36$ (E1) & $<400 \mathrm{~m}(\mathrm{Y} 1)$ & B2E1Y1 & & \\
\hline & & $>400 \mathrm{~m}(\mathrm{Y} 2)$ & B2E1Y2 & & \\
\hline & > \%36 (E2) & $<400 \mathrm{~m}(\mathrm{Y} 1)$ & B2E2Y1 & & \\
\hline & & $>400 \mathrm{~m}(\mathrm{Y} 2)$ & B2E2Y1 & & \\
\hline
\end{tabular}

\section{BULGULAR}

\section{Göğüs Çapı - Fizyografik Etmenler iliş̧kisi}

Örnek alanlardan elde edilen göğüs çapı $(\mathrm{d} 1,30)$ değerlerinin $t$ testi sonuçlarına göre; bakı etmeninin etkisiz olduğu, eğim etmeninin ise etkili olduğu belirlenmiştir. Eğimin <\%36 olduğu alanlardaki göğüs çapı değerleri daha yüksek bulunmuştur. Yükselti etmeninin ise; göğüs çapı değerleri üzerinde anlamlı etkiye sahip olduğu belirlenmiş olup, yükselti $>400 \mathrm{~m}$ deki alanlarda 
göğüs çapı değerleri daha yüksek elde edilmiştir (Çizelge 3). Göğüs çapı $(d 1,30)$ değerleri üzerinde bakı, eğim ve yükselti etmenlerinin birlikte etkilerinin denetlendiği varyans analizi sonuçlarına göre; birlikte etkili oldukları belirlenmiştir. Elde edilen sonuçlara göre dört farklı homojen grup oluşmuş ve en yüksek göğüs çapı değerleri gölgeli bakıda (B1), eğimin \%36'dan düşük olduğu (E1) ve yükseltinin 400 m'nin altında olduğu (Y1) alanlarda elde edilmiştir. En düşük göğüs çapı değerleri ise güneşli bakıda (B2), eğimin \%36'dan yüksek olduğu (E2) ve yükseltinin 400 m'nin altında olduğu (Y1) alanlarda elde edilmiştir (Çizelge 4).

\section{Ağaç Boyu - Fizyografik Etmenler îlişkisi}

Boy (h) değerleri dikkate alınarak yapılan $t$ testi sonuçlarına göre bakı etmeninin boy değerleri üzerinde güneşli bakılar lehine etkili olduğu, eğim etmeninin ise, boy değerleri üzerinde etkisiz olduğu belirlenmiştir. Yükselti etmeni bakımından yapılan değerlendirmede ise, boy değerlerinde anlamlı etkiye sahip olduğu ve yükseltinin $400 \mathrm{~m}$ 'nin üzerinde olduğu alanlardaki boy değerleri daha yüksek bulunmuştur (Çizelge 3). Boy değerleri üzerinde bakı, eğim ve yükselti etmenlerinin birlikte etkilerinin analizinden elde edilen sonuçlara göre; beş farklı homojen grup oluşmuş ve en yüksek boy değerleri güneşli bakıda (B2), eğimin $\% 36$ 'dan fazla olduğu (E2) ve yükseltinin 400 m'nin üstünde olduğu (Y2) alanlarda elde edilmiştir. En düşük boy değerleri ise gölgeli bakıda (B1), eğimin \%36'dan yüksek olduğu (E2) ve yükseltinin 400 m'nin altında olduğu alanlarda tespit edilmiştir (Çizelge 4).

\section{Kozalak Sayısı - Fizyografik Etmenler ilişkisi}

Kozalak sayıları dikkate alınarak yapılan t testi sonuçlarına göre bakı etmeninin \%95 güven düzeyi ile kozalak sayıları üzerinde etkili olduğu belirlenmiştir. Gölgeli bakılardaki kozalak sayıları, güneşli bakılardaki kozalak sayılarına göre daha yüksek bulunmuştur. Aynı şekilde, eğim etmeninin ağaçlardaki kozalak sayısı üzerinde etkili olduğu belirlenmiştir. Buna göre eğimin $<\% 36$ olduğu alanlardaki kozalak sayıları, daha yüksek bulunmuştur. Kozalak sayıları bakımından yükselti etmeninin de \%95 güven düzeyi ile kozalak sayıları üzerinde etkili olduğu tespit edilmiştir. Buna göre yükseltinin 400 m'nin üzerinde olduğu alanlardaki kozalak sayıları, yükseltinin 400 m’nin altında olduğu alanlara göre daha yüksektir (Çizelge 3). Örnek alanlarda belirlenen kozalak sayısı değerleri üzerinde bakı, eğim ve yükselti etmenlerinin birlikte etkilerinin belirlenmesi amacıyla yapılan varyans analizi sonuçlarına göre; bu etmenlerin kozalak sayısı üzerinde birlikte etkili oldukları belirlenmiştir. Elde edilen sonuçlara göre üç farklı homojen grup oluşmuş ve en yüksek kozalak sayısı değerleri gölgeli bakıda (B1), eğimin \%36'dan düşük olduğu (E1) ve yükseltinin 400 m'nin üstünde olduğu (Y2) alanlarda elde edilmiştir (Çizelge 4).

\section{Kozalak Ağırlığı - Fizyografik Etmenler iliş̧kisi}

Ortalama kozalak ağırlıkları dikkate alınarak yapılan $\mathrm{t}$ testi sonuçlarına göre bakı etmeninin ortalama kozalak ağırlığı üzerinde etkili olduğu belirlenmiştir. Gölgeli bakılardaki kozalak ağırlıkları, güneşli bakılardaki kozalak ağırlıklarına göre daha yüksek bulunmuştur. Eğim etmeninin de ortalama kozalak ağırlığı üzerinde etkili olduğu belirlenmiş ve $<\% 36$ olduğu alanlarda daha yüksek olduğu ortaya konmuştur Ortalama kozalak ağırlığı üzerinde yükselti etmeninin etkisiz olduğu belirlenmiştir (Çizelge 3). Örnek alanlarda belirlenen ortalama kozalak ağırlığı üzerinde bakı, eğim ve yükselti etmenlerinin birlikte etkilerinin analizi amacıyla yapılan varyans analizi sonuçlarına göre bu etmenlerin, ortalama kozalak ağırlı̆ı üzerinde birlikte etkili oldukları belirlenmiştir. Elde edilen sonuçlara göre; üç farklı homojen grup oluşmuş ve en yüksek ortalama kozalak ağırlığı değerleri gölgeli bakıda (B1), eğimin \%36'dan düşük olduğu (E1) ve yükseltinin 400 m'nin altında olduğu (Y1) alanlarda elde edilmiştir (Çizelge 4).

\section{Kozalak Çapı - Fizyografik Etmenler iliş̧kisi}

Kozalak çapı değerleri bakımından bakı etmeninin etkili olmadığı belirlenmiştir. Benzer şekilde yükselti etmeni de kozalak çapı üzerinde anlamlı olarak etkili bulunmamıştır. Buna karşın; eğim etmeninin kozalak çapı üzerinde anlamlı etkisinin bulunduğu belirlenmiştir. Buna göre eğimin düşük olduğu (<\%36) alanlardaki kozalak çapları eğimin yüksek olduğu (>\%36) alanlardaki kozalak çaplarından daha düşük bulunmuştur (Çizelge 3). Örnek alanlardaki ağaçların kozalak çapları üzerinde bakı, eğim ve yükselti etmenlerinin birlikte etkilerinin analizinde; kozalak çapı üzerinde anlamlı olarak etkili oldukları belirlenmiştir. Elde edilen sonuçlara göre; üç farklı 
homojen grup oluşmuş ve en yüksek kozalak çapları güneşli bakıda (B2), eğimin \%36'dan yüksek olduğu (E2) ve yükseltinin 400 m’nin altında olduğu (Y1) alanlarda elde edilmiştir (Çizelge 4).

\section{Kozalak Boyu - Fizyografik Etmenler ilişkisi}

Kozalak boyu verileri ile yapılan $t$ testi sonuçlarına göre bakı, eğim ve yükselti etmenlerinin her üçünün de kozalak boyu üzerinde etkili olmadığı belirlenmiştir (Çizelge 3). Örnek alanlardaki ağaçların kozalak boyları üzerinde bakı, eğim ve yükselti etmenlerinin birlikte etkilerinin analizi amacıyla yapılan varyans analizi sonuçlarına göre bu etmenlerin kozalak boyu üzerinde birlikte etkili olmadıkları belirlenmiştir. Elde edilen sonuçlara göre tek bir homojen grup oluşmuştur (Çizelge 4).

Çizelge 3. Fizyografik etmenlerin göğüs çapı, boy, kozalak sayısı ve kozalak ağırlığına ilişkin t-testi sonuçları

\begin{tabular}{|c|c|c|c|c|c|}
\hline \multicolumn{2}{|c|}{ Fizyografik etmenler } & Veri sayısı & Ortalama göğüs çapı (cm) & Standart sapma & Güven düzeyi \\
\hline \multirow[t]{2}{*}{ Bakı } & Gölgeli & 579 & 12,4 & 3,8 & 0,146 \\
\hline & Güneşli & 640 & 12,8 & 3,7 & \\
\hline \multirow[t]{2}{*}{ Eğim } & $<\% 36$ & 764 & 13,4 & 3,4 & 0,000 \\
\hline & $>\% 36$ & 455 & 11,3 & 3,9 & \\
\hline \multirow[t]{2}{*}{ Yükselti } & $<400 \mathrm{~m}$ & 656 & 12,2 & 3,9 & 0,000 \\
\hline & $>400 \mathrm{~m}$ & 563 & $\begin{array}{l}13,1 \\
\text { Ortalama ağaç boyu (m) }\end{array}$ & 3,4 & \\
\hline \multirow[t]{2}{*}{ Bakı } & Gölgeli & 579 & 3,65 & 7,14 & 0,000 \\
\hline & Güneşli & 640 & 3,93 & 7,39 & \\
\hline \multirow[t]{2}{*}{ Eğim } & $<\% 36$ & 764 & 3,81 & 7,25 & 0,437 \\
\hline & $>\% 36$ & 455 & 3,77 & 7,65 & \\
\hline \multirow[t]{3}{*}{ Yükselti } & $<400 \mathrm{~m}$ & 656 & 3,70 & 7,37 & 0,000 \\
\hline & $>400 \mathrm{~m}$ & 563 & 3,90 & 7,30 & \\
\hline & & & Ortalama kozalak sayısı (adet) & & \\
\hline \multirow[t]{2}{*}{ Bakı } & Gölgeli & 579 & 6,7 & 6,2 & 0,000 \\
\hline & Güneşli & 640 & 5,2 & 5,6 & \\
\hline \multirow[t]{2}{*}{ Eğim } & $<\% 36$ & 764 & 7,3 & 6,4 & 0,000 \\
\hline & $>\% 36$ & 455 & 3,6 & 4,0 & \\
\hline \multirow[t]{3}{*}{ Yükselti } & $<400 \mathrm{~m}$ & 656 & 5,2 & 5,3 & 0,000 \\
\hline & $>400 \mathrm{~m}$ & 563 & 6,8 & 6,5 & \\
\hline & & & Ortalama kozalak ağırlığı (gr) & & \\
\hline \multirow[t]{2}{*}{ Bakı } & Gölgeli & 579 & 222 & 27 & 0,000 \\
\hline & Güneşli & 640 & 214 & 22 & \\
\hline \multirow[t]{2}{*}{ Eğim } & $<\% 36$ & 764 & 222 & 29 & 0,000 \\
\hline & $>\% 36$ & 455 & 210 & 16 & \\
\hline \multirow[t]{3}{*}{ Yükselti } & $<400 \mathrm{~m}$ & 656 & 219 & 28 & 0,254 \\
\hline & $>400 \mathrm{~m}$ & 563 & 217 & 22 & \\
\hline & & & Kozalak çapı (cm) & & \\
\hline \multirow[t]{2}{*}{ Bakı } & Gölgeli & 74 & 5,0 & 0,54 & 0,157 \\
\hline & Güneşli & 84 & 5,1 & 0,58 & \\
\hline \multirow[t]{2}{*}{ Eğim } & $<\% 36$ & 98 & 4,9 & 0,61 & 0,003 \\
\hline & $>\% 36$ & 60 & 5,2 & 0,43 & \\
\hline \multirow[t]{3}{*}{ Yükselti } & $<400 \mathrm{~m}$ & 85 & 5,0 & 0,62 & 0,359 \\
\hline & $>400 \mathrm{~m}$ & 73 & 5,1 & 0,48 & \\
\hline & & & Kozalak boyu (cm) & & \\
\hline \multirow[t]{2}{*}{ Bakı } & Gölgeli & 74 & 6,7 & 0,65 & 0,889 \\
\hline & Güneşli & 84 & 6,7 & 0,70 & \\
\hline \multirow[t]{2}{*}{ Eğim } & $<\% 36$ & 98 & 6,8 & 0,67 & 0,486 \\
\hline & $>\% 36$ & 60 & 6,7 & 0,69 & \\
\hline \multirow[t]{2}{*}{ Yükselti } & $<400 \mathrm{~m}$ & 85 & 6,6 & 0,70 & 0,057 \\
\hline & $>400 \mathrm{~m}$ & 73 & 6,8 & 0,63 & \\
\hline
\end{tabular}


Çizelge 4. Fizyografik etmenlerin göğüs çapı, boy ve kozalak parametrelerine ilişkin varyans analizi sonuçları

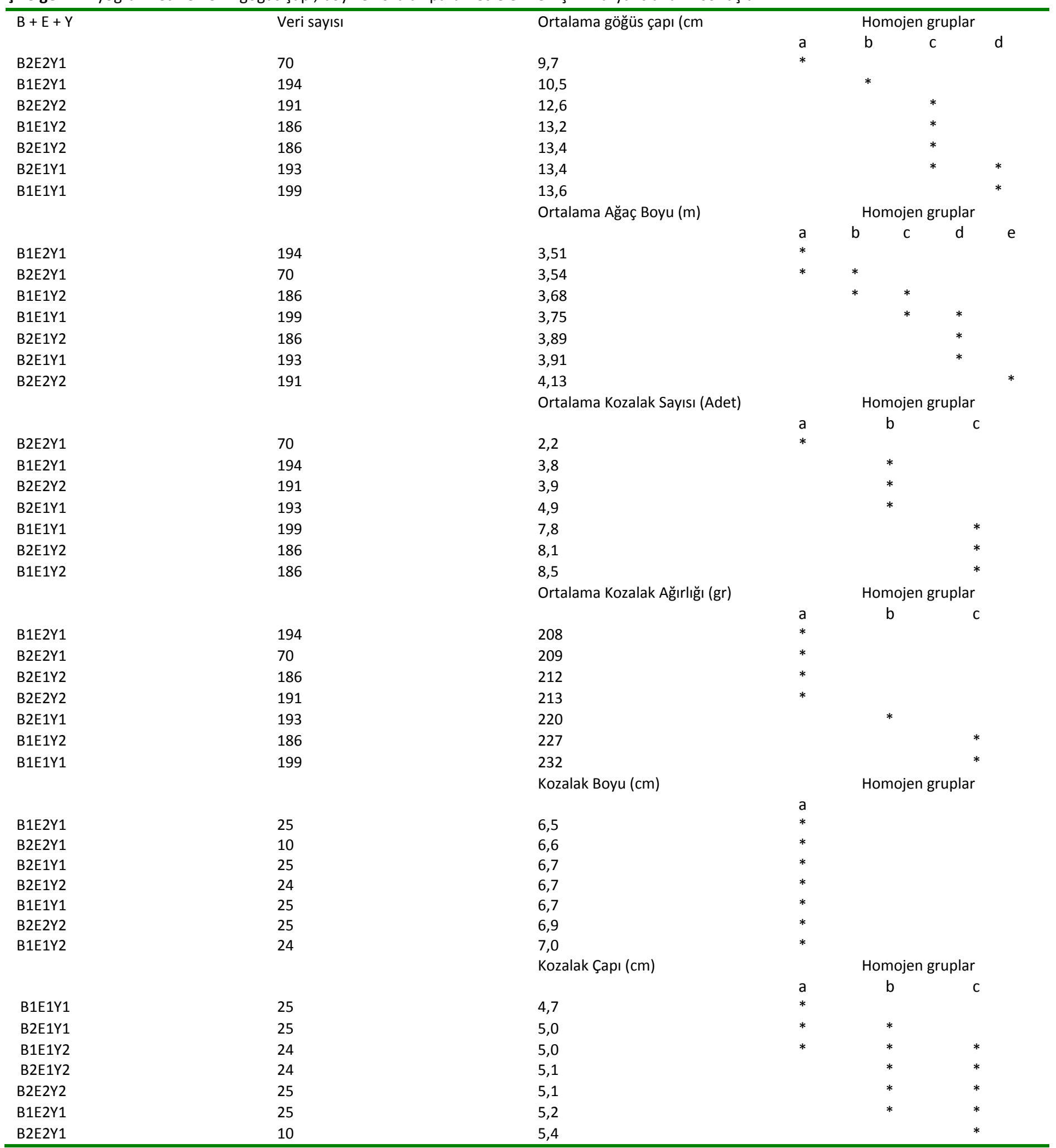

\section{Fizyografik Etmenler - Değişkenler Korelasyonu}

Boy, göğüs çapı, kozalak sayısı, kozalak ağırlığı, kozalak boyu ve kozalak çapı gibi değişkenler ile bakı, eğim ve yükselti etmenleri arasındaki ilişkiyi belirlemek için yapılan korelasyon analizinde, göğüs çapı üzerinde eğim ve yükselti etmenlerinin pozitif yönde bir etkisi olduğu belirlenmiştir. Bir diğer ifadeyle, örnek sahalarda elde edilen göğüs çaplarının eğim ve yükselti artışına bağlı olarak arttığı görülmüştür. Boy üzerinde ise sadece bakı ve yükselti etmenleri pozitif etki göstermektedir. 
Dolayısıyla güneşli bakıda ve $400 \mathrm{~m}$ nin üzerindeki örnek alanlarda daha yüksek boy değerleri elde edilmiştir. Kozalak verimliliğine ilişkin ölçütlerden biri olan kozalak sayısı ile fizyografik etmenler arasındaki ilişki incelendiğinde, bakı ve eğim negatif, yükselti ise pozitif ilişki göstermektedir. Kozalak ağırlığı üzerinde ise sadece eğim etmeni negatif bir etkiye sahiptir. Kozalak boyutlarına ilişkin bir ölçüt olan kozalak çapı ile her üç etmenin de, pozitif ilişki gösterdiği belirlenmiştir. Kozalak boyutlarına ilişkin diğer bir ölçüt olan kozalak boyu ise, eğim etmeni ile negatif, yükselti etmeni ile pozitif bir ilişki göstermektedir (Çizelge 5).

Çizelge 5. Fizyografik etmenlerle değişkenler arasındaki korelasyon analizi değerleri

\begin{tabular}{|c|c|c|c|c|c|c|}
\hline $\begin{array}{l}\text { Fizyografik } \\
\text { etmenler }\end{array}$ & Göğüs çapı (cm) & Boy (m) & $\begin{array}{l}\text { Kozalak sayısı } \\
\text { (adet) }\end{array}$ & $\begin{array}{l}\text { Ortalama kozalak } \\
\text { ağırlığı (kg) }\end{array}$ & Kozalak çapı (cm) & $\begin{array}{l}\text { Kozalak boyu } \\
(\mathrm{cm})\end{array}$ \\
\hline Bakı & $0,042^{n s}$ & $0,190 * * *$ & $-0,123 * * *$ & $-0,159^{*}$ & $0,113^{\mathrm{ns}}$ & $-0,011^{n s}$ \\
\hline Eğim (\%) & $-0,272 * * *$ & $-0,022^{n s}$ & $-0,304 * * *$ & $-0,243 * *$ & $0,234^{* *}$ & $-0,056^{\mathrm{ns}}$ \\
\hline Yükselti (m) & $0,116^{* * *}$ & $0,136 * * *$ & $0,139 * * *$ & $-0,027^{\mathrm{ns}}$ & $0,073 \mathrm{~ns}$ & $0,151^{\mathrm{ns}}$ \\
\hline
\end{tabular}

***: $p<0,000 \quad * *: p<0,010 \quad *: p<0,050 \quad$ ns: $p>0,050$

\section{TARTIŞMA VE SONUÇ}

Fıstıkçamı Balıkesir-Burhaniye yöresindeki ağaçlandırmaların 20 yıllık sonuçlarının değerlendirdiği araştırma t-testi bulgularına göre; eğim, bakı ve yükseklik kademelerinin değerlendirmeye alınan çap, boy ve kozalak özellikleri bakımından farklı etkilere sahip oldukları görülmektedir. Göğüs çapına bakı etkisiz iken, eğim ve yükselti etmeni etkili bulunmuştur. Ağaç boyuna bakı etmeni etkili, eğim etmeni etkisiz, yükselti etmeni ise etkilidir. Her üç etmenin birlikte etkilerinin değerlendirilmesinde; göğüs çapı bakımından B1E1Y1 ve B2E1Y1 etkileşimi, boy bakımından ise B2E2Y2 etkileşimi en iyi sonucu vermiştir. Fıstıkçamı ağaçlandırmalarında yapılan benzer değerlendirmelerde, araştırmaya konu alanların yaşlarına göre incelenen parametreler bakımından farklılıklar bulunmaktadır. Özdarçın (2011), 7 yaşında değerlendirmeye alınan ağaçlandırmalarda eğimin, çap ve boy üzerinde anlamlı etkiye sahip olduğunu belirtirken, 23 yaşındaki plantasyonlarda bu etkinin bulunmadığını belirtmektedir. Bu durum ilerleyen yaşlarda bakı, eğim gibi kriterlerin etkisinin ortadan kalktığını düşündürmekte, ancak yöresel olarak farklılıkların devam edebileceğini de göstermektedir. Öte yandan benzer arazi koşullarında bile aynı yaşı ı fıstıkçamı meşcerelerinde çap ve boylar arasında önemli değişkenlikler bulunduğunun (Ganatsas ve ark. 2008) belirtilmesi de çalışmamızda elde edilen farklılıkların olağan olduğunu göstermektedir.

Kozalak özellikleri bakımından elde edilen verilerde ise; bakının kozalak sayısına ve kozalak ağırlığına, eğimin kozalak sayısına, kozalak ağırlığına ve kozalak çapına, yükseltinin ise kozalak sayısına anlamlı etkiye sahip oldukları belirlenmiştir. $\mathrm{Bu}$ bulgulardan incelenen değişkenler bakımından farklılıklar olduğunu, her üç fizyografik faktörün ise, kozalak sayısına anlamlı etkiye sahip olduğunu söyleyebiliriz. Her üç etmenin birlikte etkilerinin değerlendirilmesinde; ortalama kozalak sayısı bakımından B1E1Y1, B2E1Y2 ve B1E1Y2 etkileşimleri, ortalama kozalak ağılığı bakımından B1E1Y2 ve B1E1Y1 etkileşimleri, kozalak çapı bakımından B1E1Y2, B2E1Y2, $B 2 E 2 Y 2, B 1 E 2 Y 1$ ve B2E2Y1 etkileşimleri en iyi sonucu vermiştir. Kozalak boyu bakımından etkileşimler arasında anlamlı farklılık bulunamamıştır. Sonuçlar, fıstıkçamının en önemli ürünü olan çam fıstığının birim alandan daha fazla elde edilebilmesi açısından incelenen parametrelerin önemli olduğunu göstermektedir. Ve fakat bunun dışında pek çok etken de kozalak verimine etki etmektedir. Nitekim Calama ve Montero (2007)'nun ifade ettikleri gibi, fıstıkçamında kozalakların ortalama ağırlığı arazi koşullarına bağlı bir değişkendir ve yine kozalakların ortalama ağırlığı büyük oranda kozalaklar olgunlaşmadan önce ilkbahardaki hava koşullarına bağlı olarak farklılık göstermektedir. Öte yandan, kozalak üretiminde ağaçlar arasındaki mesafenin de güçlü bir etkiye sahip olduğu belirtilmektedir (Gonçalves ve Pommerening 2012).

Bakı, eğim ve yükselti etmeninin değişkenler üzerinde birlikte etkileri korelasyon analizi ile ilişkilendirildiğinde; ağaç boyu ve kozalak çapı üzerinde pozitif, kozalak sayısı ve kozalak ağırlığı üzerinde, negatif etki gösterdikleri görülmektedir. Bu tarz etkiler tür bazında yapılan 
araştırmalarda da değişkenlikler gösterebilmektedir. Mughal ve Thapliyal (2012)' e göre Cedrus deodara'da kozalak çapı ve kozalak ağırlı̆ı ile yükselti arasında negatif bir korelasyon bulunmakta ve kozalak uzunluğu ve kozalak çapı kuzeyden güneye doğru artarak, yükseltiyle negatif bir korelasyon göstermektedir. Buna karşın, Pinus canariensis'de, kozalak uzunluğu ile yükseklik arasında pozitif ilişki bulunmaktadır (Gil ve ark. 2002). Pinus roxburghii'de farklı yükseklik kademeleri kozalak çapı ve kozalak ağırlığı üzerinde anlamlı etkiye sahip olup, en yüksek kozalak çapı ve ağırlığı çalışılan 0-2000 m yükseklikleri arasında orta kademe olan 800-1500 m yükseklikleri arasında elde edilmiştir (Bhardwaj ve ark. 2016). Öte yandan Pinus tabulaeformis türünde yapılan çalışma sonuçlarında, kozalak uzunluğu ve çapı gibi morfolojik özellikler bakımından önemli bir varyasyon bulunduğu ve fenotipik bu değişikliklerin genetik farklılıktan çok iklim ya da coğrafik varyasyonlarla ilişkilendirildiği belirtilmektedir (Mingfei ve ark. 2011). Pinus kesiya'da ise, 950-1650 m arasında değişen yükseltilerden seçilen üstün ağaçlardan elde edilen kozalaklarda yükseklikle kozalak ağırlığı ve tohum çapı arasında pozitif korelasyon bulunmuştur (Singh ve ark. 2015). Çalışmamızda örnek alanlar arasında yükseklik farkının 134 metre olmasına karşın, incelenen değişkenlerin, kozalak çapında ve ağaç boyunda pozitif korelasyon, kozalak sayısı ve kozalak ağırlı̆ında negatif korelasyon göstermesi fıstıkçamında kozalak özellikleri üzerinde bu değişkenlerin önemli olduğunu belirtmektedir.

Fıstıkçamında; kozalak üretiminde ağaçlar arasındaki mesafenin güçlü bir etkiye sahip olması (Gonçalves ve Pommerening 2012), şiddetli ve orta dereceli aralamaların hem kozalak üretimine ve hem de ağaçlardaki göğüs yüksekliği çap artışında anlamlı bir farklılığa neden olması (Moreno-Fernández ve ark. 2013), budama uygulamasının göğüs çapı ve boy üzerinde etki yapması (Kırdar ve ark. 2010), benzer arazi koşullarında bile aynı yaşlı fıstıkçamı meşcerelerinde çap ve boylar arasında önemli farklııkların bulunması ve genç meşcerelerin daha yaşlı meşcerelere göre ağır kozalaklar oluşturması (Ganatsas ve ark. 2008), kozalakların ortalama ağırlığının arazi koşullarına bağlı bir değişken olması, öte yandan daha geniş ve ağır kozalakların dolu tohum bakımından daha yüksek oran içermesi (Calama ve Montero 2007), bir önceki yıldaki yağış miktarı ile yıllık ortalama kozalak ağırlığı arasında güçlü bir korelasyonun bulunduğunun ve ortalama kozalak ağırlığının yıllık olarak yüksek oranda değişkenlik gösterebileceğinin bildirilmesi (Mutke ve ark. 2005b), daha ağır kozalakların elde edilmesi ve bunun bir sonucu olarak içlerinde daha fazla sayıda çamfıstığının oluşması için yağış azlığının meyve verimliliği üzerindeki olumsuz etkisini azaltmak amacıyla sulama tavsiyesinde bulunulması (Loewe-Muñoz ve ark. 2016) gibi pek çok araştırmanın sonuçları ve çalışmamızdan elde ettiğimiz sonuçlar, yeni fıstıkçamı plantasyonlarının oluşturulmasında çok farklı değişkenlerin göz önünde bulundurulması ve var olan doğal ve yapay fıstıkçamı meşcerelerinde silvikültürel işlemlerin çap artımı, büyüme ve çam fıstığı ürününün en yüksek şekilde olmasını sağlayacak biçimde planlanması gerektiğini göstermektedir.

\section{ÖNERILER}

Çalışmanın sonuçlarına göre; Balıkesir-Burhaniye yöresinde yapılmış araştırmaya konu fıstıkçamı ağaçlandırmasının incelenen özellikler bakımından farklılıklar gösterdiği belirlenmiştir. Gerek çalışmanın yapıldığı yörede ve gerekse Türkiye'nin değişik bölgelerinde oluşturulacak yeni plantasyonların yer seçiminde; arazi yapısı eğim, bakı ve yükseklik gibi faktörlerin dikkatle göz önünde bulundurulacağı, bunun dışında yağış ve sıcaklık gibi iklim faktörlerinin de, göz önünde bulundurulacağı çok değişkenli projelendirmelerin yapılması yararlı olacaktır.

Çam fıstığı değerli bir ekonomik kaynaktır. Kozalak ağırlığının ve kozalak boyutlarının tohum ağırlığı ve tohum sayısı ile ilişkili olması ve yine göğüs çapı ve ağaç boyunun kozalak özelliklerini etkiliyor olması, bu değerlerin en yüksek seviyeye çıkmasını sağlayacak koşulların oluşturulmasını gerekli kılmaktadır. O nedenle; saf ve karışık doğal fıstıkçamı meşcerelerinde ve yapay olarak oluşturulmuş ve yeni oluşturulacak fıstıkçamı plantasyonlarında aralama, budama gibi silvikültürel bakım önlemleri ile bunların müdahale yoğunluğunun farklı bölgelerde araştırmalarla ortaya konulmasının oldukça önemli olduğu görülmektedir. 
Burhaniye yöresinde, fıstıkçamı ağaçlandırmalarının başarılı olması bu türün sosyo-ekonomik açıdan yerel halka önemli katkılar sağlayabileceği gerçeğini de ortaya çıkarmaktadır. Nitekim bu yörede Fıstıkçamına "akıllı çam" denilmektedir. Fıstıkçamının gerek odununun ve gerekse daha çok "çam fıstı̆̆ı" adı verilen tohumunun değerli olması ve giderek daha da değerlenmeleri, bu tür ile yapılan ağaçlandırma çalışmalarının öneminin gelecekte daha da artacağını ortaya koymaktadır.

\section{KAYNAKLAR}

Anonim (1985) Bahadınlı serisi orman içi ağaçlandırma projesi, Ağaçlandırma ve Erozyon Kontrolü Genel Müdürlüğü, Balıkesir.

Anonim (2006) Fıstıkçamı eylem planı (2006-2010). Orman Genel Müdürlüğü, Ankara.

Anşin R, Özkan ZC (1993) Tohumlu bitkiler odunsu taksonlar, K.T.Ü. Orman Fakültesi Yayın No:19, Trabzon

Atalay i (1994) Türkiye vejetasyon coğrafyası. Ege Üniversitesi Basımevi, İzmir

Batu F (1995) Uygulamalı istatistik yöntemler, K.T.Ü. Orman Fakültesi Yayın No: 22, Trabzon.

Bhardwaj P, Sharma K, Khosla PK (2016) Variation in cone characteristics of Pinus roxburghii. IJBPAS, 5 (11): 2763-2770.

Calama R, Montero G (2007) Cone and seed production from stone pine (Pinus pinea L.) stands in Central Range (Spain). Eur J Forest Res, 126: 23-35.

Çepel N (1995) Orman ekolojisi, i.ü. Orman Fakültesi Yayın No: 433, istanbul.

Fady B, Fineschi S, Vendramin, GG (2004) EUFORGEN Technical guidelines for genetic conservation and use for Italian stone pine (Pinus pinea L.), Int. Plant Genetic Res. Inst. Rome, Italy, $6 \mathrm{~s}$.

Ganatsas P, Tsakaldimi M, Thanos C (2008) Seed and cone diversity and seed germination of Pinus pinea in Strofylia Site of the Natura 2000 Network. Biodivers Conserv, 17: 2427-2439.

Gil L, Climent J, Nanos N, Mutke S, Ortiz I, Schiler G (2002) Cone morphology variation in Pinus canariensis. Plant Syst Evol, 235: 3551.

Gonçalves AC, Pommerening, A (2012) Spatial dynamics of cone production in Mediterranean climates: A case study of Pinus pinea L. in Portugal. Forest Ecology and Management. 266: 83-93.

Kırdar E, Özel HB, Ertekin M (2010) Fıstıkçamı (Pinus pinea L.) ağaçlandırmalarında budama uygulamasının boy ve çap gelişimi üzerine etkileri, Bartın Orman Fakültesi Dergisi, 12 (18): 1-10.

Kurt R, Karayılmazlar S, Imren E, Cabuk Y (2016) Türkiye ormancilık sektöründe odun dışı orman ürünleri: ihracat analizi. Bartın Orman Fakültesi Dergisi, 18 (2): 158-167.

Loewe-Muñoz V, Balzarini M, Álvarez A, Delard C, Ma-Navarro R (2016) Fruit productivity of Stone pine (Pinus pinea L.) along a climatic gradient in Chile, Agricultural and Forest Meteorology, 223:1-14.

Mingfei Jl, Xiaowei Zhang, Zhiqiang Wang, Qiang Zhang, Jianming Deng (2011) Intra-versus inter population variation of cone and seed morphological variation of cone and seed morphological traits of Pinus tabulaeformis Carr. In northern China: impact of climatic conditions. Polish Journal of Ecology, 59 (4): 717-727.

Montes F, Hernández MJ, Calama R, Cañellas I (2006) Extended length rotation to integrate timber and pine nut production with the conservation of structural diversity in a Pinus pinea (L.) forest, Ann. For. Sci. 63: 773-781.

Moreno-Fernández D, Cañellas I, Calama R, Gordo J, Sánchez-González $M$ (2013) Thinning increases cone production of stone pine (Pinus pinea L.) stands in the Northern Plateau (Spain). Annals of Forest Science, 70: 761-768.

Mughal AH, Thapliyal RC (2012) Provenance variation in cone and seed characteristics of Cedrus deodara (D. DON) G. DON in Jammu and Kashmir. Forestry Studies in China 14 (3): 193-199.

Mutke S, Gordo J, Gil L (2005a) Variability of Mediterranean Stone pine cone production: Yield loss as response to climate change. Agricultural and Forest Meteorology. 132: 263-272.

Mutke S, Gordo J, Gil L (2005b) Cone Yield Characterization of a Stone Pine (Pinus pinea L.) Clone Bank. Silvae Genetica, 54 (4-5): 189197.

Nergiz C, Dönmez i (2004) Chemical composition and nutritive value of Pinus pinea L. Seeds. Food Chemistry, 86: 365-368.

Özdamar K (2002) Paket programlar ile istatistiksel veri analizi, Kaan Kitabevi, Eskişehir

Sayman M, Akbin G ve Kılcı M (2006) Fıstıkçamı (Pinus pinea L.) kurak ve yarı kurak bölge ağaçlandırmaları için uygun bir tür müdür? Çevre ve Orman Bakanlığı AGM, Türkiye'de Yarıkurak Mıntıka Ağaçlandırmalarının Değerlendirilmesi Çalıştayı, Ürgüp, I.Cilt, 343352.

Singh O, Bordoloi S, Mahanta N (2015) Variability in cone, seed and seedling characteristics of Pinus kesiya Royle ex. Gordon. J. For. Res., 26 (2) :331-337.

URL (2014) http://www.milliyet.com.tr/fistikcami-kozalagi-ihalesindefiyatlar-adana yerelhaber-36442/ Erişim tarihi: 07.05.2017.

Yılmaz M, Tonguç F, Bozali, N (2010) Kahramanmaraş-Önsen doğal fıstıkçamı ormanı üzerine genel bir değerlendirme. III. Ulusal Karadeniz Ormancılık Kongresi Artvin, Cilt: III, 895-904 